\title{
MIR30C2 wt Allele
}

National Cancer Institute

\section{Source}

National Cancer Institute. MIR30C2 wt Allele. NCI Thesaurus. Code C162385.

Human MIR30C2 wild-type allele is located in the vicinity of $6 q 13$ and is approximately 72 bases in length. This allele, which encodes MIR30C2 pre-miRNA, may be involved in wound healing and angiogenesis. 